\title{
Molecular evolution of the leptin exon 3 in some species of the family Canidae
}

\author{
Agata ChmurzynskA ${ }^{\mathrm{a}}$, Magdalena ZajaC ${ }^{\mathrm{a}, \mathrm{b}}$ \\ Marek SwITONSKI ${ }^{\mathrm{a} *}$ \\ a Department of Genetics and Animal Breeding, \\ August Cieszkowski Agricultural University of Poznan, Poland \\ ${ }^{\mathrm{b}}$ Institute of Human Genetics, Polish Academy of Sciences, Poznan, Poland
}

(Received 9 September 2002; accepted 5 February 2003)

\begin{abstract}
The structure of the leptin gene seems to be well conserved. The polymorphism of this gene in four species belonging to the Canidae family (the dog (Canis familiaris) - 16 different breeds, the Chinese racoon dog (Nyctereutes procyonoides procyonoides), the red fox (Vulpes vulpes) and the arctic fox (Alopex lagopus)) were studied with the use of single strand conformation polymorphism (SSCP), restriction fragment length polymorphism (RFLP) and DNA sequencing techniques. For exon 2, all species presented the same SSCP pattern, while in exon 3 some differences were found. DNA sequencing of exon 3 revealed the presence of six nucleotide substitutions, differentiating the studied species. Three of them cause amino acid substitutions as well. For all dog breeds studied, SSCP patterns were identical.
\end{abstract}

leptin / Canidae / polymorphism

\section{INTRODUCTION}

The Canidae family consists of 36 species and can be divided into three groups: the red fox-like canids (e.g. the red and Arctic fox), the South American foxes (e.g. pampas fox) and the wolf-like canids. The species such as the racoon dog and the bat-eared fox are monotypic genera and represent distinct lineages [21]. The racoon dog has the most primitive chromosome set, including many ancestral segments and additionally some blocks are homologous to those in cats [14]. The chromosome number within the Canidae family ranges from 34 ( $+\mathrm{B}$ chromosomes) in the red fox to 78 in the dog, wolf and jackal. The most phenotypically diverse canid is the domestic dog (Canis familiaris) [20]. The high degree of intrabreed homogeneity makes the dog an attractive model for studying hereditary diseases [15] and also the correlation between genotype and phenotype, especially concerning body size and shape.

\footnotetext{
* Correspondence and reprints

E-mail: switonsk@jay.au.poznan.pl
} 
The leptin gene was identified in $o b / o b$ mice in 1994 [22]. This gene is organised into three exons separated by two introns. The first exon and the first intron occur in the $5^{\prime}$-untranslated region (UTR). The second exon codes for 48 amino acids. The third exon consists of the coding region (codes for 118 or alternatively 119 amino acids) and 3'UTR [8]. The structure of the gene is very conservative. The identity of the nucleotide sequence between the dog and other studied animals ranges from $93.5 \%$ for the cat to $83.3 \%$ for the rat [16]. Leptin is secreted by white adipocytes and is responsible for the regulation of body weight and energy homeostasis [6]. The leptin protein is a monomer which consists of four antiparallel $\alpha$-helices (A, B, C and D) connected by AB, $\mathrm{BC}$ and $\mathrm{CD}$ loops [23].

Our goal was to determine intraspecies polymorphisms in the coding sequence (exons 2 and 3 ) of the canine leptin gene and the detection of a mutation which occurred in the course of evolution in selected species of the Canidae family: the domestic dog (Canis familiaris), the Chinese racoon dog (Nyctereutes procyonoides procyonoides), the arctic fox (Alopex lagopus) and the red fox (Vulpes vulpes). It should be mentioned that foxes and the racoon dog are fur animals and are of an economic importance in some countries.

\section{MATERIALS AND METHODS}

\subsection{PCR-SSCP}

DNA samples from 35 dogs representing 16 breeds (namely: Caucasian Shepherd, Dachshund, Rottweiler, German Shepherd, Cane Corso, Briard, Mallorquin Bulldog, Beagle, Afghan Hound, Saint Bernard, American Stafford Terrier, Samoyed, Chow-Chow, Doberman Pinscher, Newfoundland, Irish Wolfhound), as well as 15 arctic foxes, 15 red foxes and 12 racoon dogs were used in screening for leptin gene variants. All foxes and racoon dogs originated from two fur animal farms. Three primer pairs were chosen in order to amplify DNA fragments using the coding sequence (CDS) of canine leptin (GenBank accession number AB 020986). The first primer pair LEP2F 5'TTG TGG ACC TCT GTG CCG ATT C3' and LEP2R 5'ATC CTG GCG ACA ATC GTC TTG3' amplified the region from nucleotide 37-156 of the CDS and comprised exon 2 (24 nucleotides of exon 2 were not included). The PCR reaction was run in the thermocycler UNOII (Biometra). The cycling profile was: $94{ }^{\circ} \mathrm{C}(4 \mathrm{~min}) 1 \mathrm{cycle}, 94^{\circ} \mathrm{C}(30 \mathrm{~s}), 52^{\circ} \mathrm{C}(35 \mathrm{~s}), 72^{\circ} \mathrm{C}(30 \mathrm{~s}) 30$ cycles, $72^{\circ} \mathrm{C}$ ( $\left.7 \mathrm{~min}\right) 1$ cycle. The second primer pair LEP $3 \mathrm{~F} 5^{\prime} \mathrm{AGT}$ CTG TCT CCT CCA AAC $3^{\prime}$ and LEP3R 5' AGG CTC TCA AAG GTC TCC $3^{\prime}$ amplified the region from nucleotide $177-423$ of the CDS and comprised a part of exon 3. The cycling profile was: $94{ }^{\circ} \mathrm{C}(4 \mathrm{~min}) 1 \mathrm{cycle}, 94^{\circ} \mathrm{C}(30 \mathrm{~s}), 56^{\circ} \mathrm{C}(35 \mathrm{~s}), 72^{\circ} \mathrm{C}$ (40 s) 30 cycles, $72^{\circ} \mathrm{C}(7 \mathrm{~min}) 1$ cycle. The third primer pair LEP3F $25^{\prime} \mathrm{CAG}$ 
GGG CCT GGA GAC CTT TGA GA3' and LEP3R2 5'GAA ACG GCT AGG GGC CAG GAT AAA3' amplified the region from nucleotide 397-642 of the CDS and comprised a part of exon 3 and 107 nucleotides of the $3^{\prime} \mathrm{UTR}$. The PCR reaction mixture (total of $30 \mu \mathrm{L}$ ) contained $100 \mathrm{ng}$ of genomic DNA, $3 \mu \mathrm{L}$ of $10 \times$ PCR buffer $\left(1 \times\right.$ is $10 \mathrm{mM}$ Tris- $\mathrm{HCl}$, pH $8.8,1.5 \mathrm{mM} \mathrm{MgCl}_{2}$, $50 \mathrm{mM} \mathrm{KCl}$ and $0.1 \%$ Triton X-100), 25 pmol of each primer, $170 \mu \mathrm{M}$ of dNTP and $0.9 \mathrm{U}$ of Taq polymerase.

The amplified samples were mixed with single strand conformation polymorphism (SSCP) buffer $-0.1 \%$ bromophenol blue and $0.1 \%$ xylene cyanole in formamide. Before loading the samples were denaturated for $5 \mathrm{~min}$ at $95^{\circ} \mathrm{C}$ and kept for $5 \mathrm{~min}$ on ice. Then $10 \mu \mathrm{L}$ of this mixture was applied to a $9 \%$ polyacrylamide gel (49:1 acrylamide:bis), $10 \%(\mathrm{~V} / \mathrm{V})$ glycerol and $0.5 \times \mathrm{TBE}$ buffer. Electrophoresis was run overnight at room temperature. Then the gel was stained with silver nitrate according to a standard protocol. Briefly, the gel was washed in $10 \%$ ethanol for $15 \mathrm{~min}$, and then transferred to $1 \% \mathrm{HNO}_{3}$ for 10 min. Next the gel was incubated for $30 \mathrm{~min}$ in $0.2 \%$ silver nitrate with the addition of formaldehyde (the final concentration of formaldehyde was $0.12 \%$ ). The developing reaction (approximately 20-30 $\mathrm{min}$ ) was performed with the use of $3 \%$ sodium carbonate with the addition of formaldehyde (the final concentration of formaldehyde was $0.05 \%$ ) and stopped by $10 \%$ acetic acid.

Based on the findings of SSCP the possibly polymorphic DNA samples were sequenced at the Institute of Biochemistry and Biophysics, Polish Academy of Sciences, Warsaw, Poland. The sequences were submitted to GenBank and the following accession numbers were given: the dog sequence AY098739, the Chinese racoon dog sequence AY098741, the red fox sequence AY098742 and the arctic fox sequence AY098740. The amino acid sequences were predicted on the basis of the obtained nucleotide sequences. A comparison of the sequences was performed with BLAST 2 Sequences [19].

\subsection{RFLP}

Amplified samples were digested with restriction enzymes: FokI, HinfI, HaeIII (fragment LEP2F/LEP2R), DdeI, MspI, FokI, SmaI (fragment LEP3F/ LEP3R) and TaqI, HaeIII (fragment LEP3F2/LEP3R2). The digestion fragments were identified on a $2 \%$ agarose gel or on a $12 \%$ polyacrylamide gel.

\section{RESULTS}

Patterns of migration in exon 2 were identical as well for 16 canine breeds as for all studied species. The variability was identified only in exon 3 (Figs. 1 and 2). Thus, exon 3 of all the studied species was sequenced and the data were submitted to GenBank (accession numbers described in Materials and Methods). A comparison of the DNA sequences revealed six polymorphic 


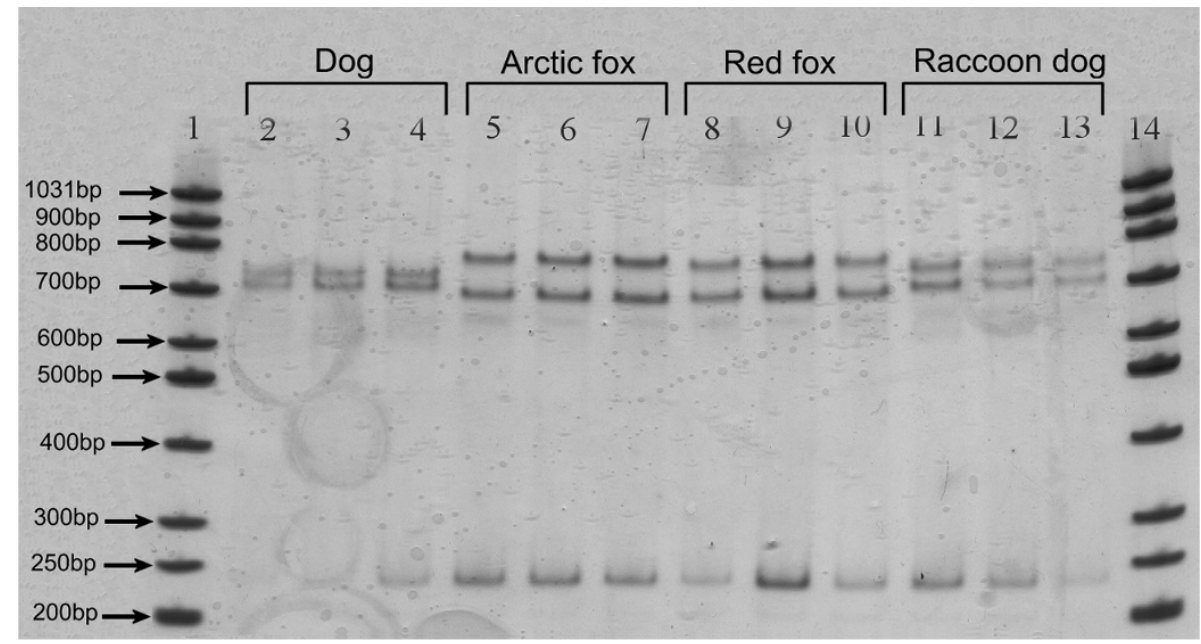

Figure 1. SSCP patterns of the first part (247 bp) of leptin exon 3. Lanes 1 and 14: molecular weight standard (GeneRuler ${ }^{\mathrm{TM}} 50$ bp DNA Ladder, Fermentas); lanes 2 to 4: the dog DNA; lanes 5 to 7: the arctic fox DNA; lanes 8 to 10: the red fox DNA; lanes 11 to 13: the racoon dog DNA.

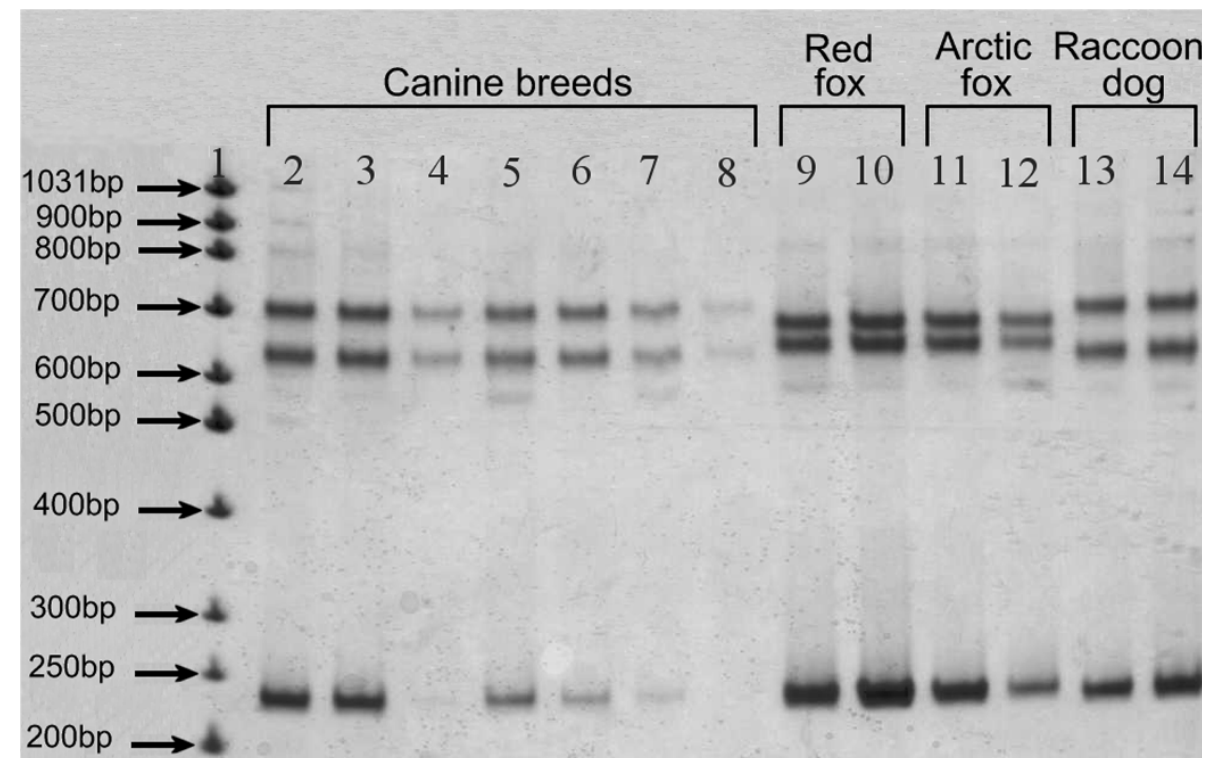

Figure 2. SSCP analysis of the second part of the leptin exon 3. Lane 1: molecular weight standard (GeneRuler ${ }^{\mathrm{TM}} 50 \mathrm{bp}$ DNA Ladder, Fermentas); lanes 2 to 8: DNA of the different canine breeds; lanes 9 and 10: the red fox DNA; lanes 11 and 12: the arctic fox DNA; lanes 13 and 14: the racoon dog DNA. 
Table I. Polymorphic sites in exon 3 of the leptin gene, identified in the dog (CFA), Chinese racoon dog (NPR), arctic fox (ALA), and red fox (VVU). Coded amino acids are shown in parentheses.

\begin{tabular}{|c|c|c|c|c|}
\hline Localisation & CFA & NPR & ALA & VVU \\
\hline Codon 65 & GGG (G) & GGG (G) & GGG (G) & GGA (G) \\
\hline Codon 74 & $\operatorname{AGG}(\mathrm{R})$ & AGG (R) & AAG (K) & AAG $(K)$ \\
\hline Codon 87 & $\operatorname{AAC}(\mathrm{N})$ & $\operatorname{ACC}(\mathrm{T})$ & $\mathrm{ACC}(\mathrm{T})$ & $\operatorname{ACC}(\mathrm{T})$ \\
\hline Codon 121 & CGG (R) & CGG (R) & CGG (R) & $\mathrm{CCG}(\mathrm{P})$ \\
\hline $3^{\prime} \mathrm{UTR}, 6 \mathrm{bp}^{1}$ & CTC & CTC & CTT & CTT \\
\hline $3^{\prime} \mathrm{UTR}, 53 \mathrm{bp}^{1}$ & GTG & GTG & GGG & GGG \\
\hline
\end{tabular}

${ }^{1}$ downstream of the termination codon.

sites (Tab. I). One nucleotide substitution was silent (codon 65, 17th amino acid of the third exon), while the other changed the amino acid sequence. Substitutions in two codons (74 and 87 ) caused changes in the primary polypeptide structure; however, the amino acids involved have the same chemical properties. In foxes, lysine was present at position 74 but in the dog and the racoon dogs it was replaced by arginine. Likewise, in the dog, asparagine was present at the 87th position but in the other species studied it was replaced by threonine. The third substitution occurred at the 121st position in the red fox and caused replacement of arginine by proline, which has different chemical properties.

Some of the nucleotide substitutions change the consensus sequences of three restriction enzymes. PCR-RFLP analysis with the use of SmaI (the consensus sequence at codon 74), FokI (codon 121) and TaqI (3'UTR, 6 bp) was performed, and in all cases the expected RFLP patterns were observed (data not shown).

The comparison of nucleotide and predicted amino acid sequences revealed a high degree of leptin identity in the Canidae family. The similarity of the nucleotide sequences was estimated as $98-99 \%$ and the amino acid sequences as $97-99 \%$.

\section{DISCUSSION}

The novel kind of genetic markers - single nucleotide polymorphism (SNP) is a suitable tool for analysing the single gene and also the whole genome. So far a few polymorphic variants of the leptin gene have been described in humans, pigs and cattle (Tab. II), however, human lep mutations are likely to be rare [6]. For example, testing of 105 obese patients did not reveal polymorphisms in the coding sequence of the gene [12]. Diversity of the leptin gene was studied in 
Table II. Some polymorphisms identified in exon 2 and exon 3 of the human, porcine and bovine leptin gene.

\begin{tabular}{llcc}
\hline Species & \multicolumn{1}{c}{ Polymorphism } & Localisation & References \\
\hline Homo sapiens & G144A substitution & Exon 2 & {$[10]$} \\
& G328A substitution & Exon 3 & {$[10]$} \\
& G deletion (codon 133) & Exon 3 & {$[13]$} \\
Sus scrofa & C/T (codon 105) & Exon 3 & {$[18]$} \\
& RFLP $($ Hinf I) T3469C & Exon 3 & {$[17]$} \\
Bos taurus & G3714T & Exon 3 & {$[9]$} \\
& C/T & Exon 2 & {$[4]$} \\
& C/T, A/G & Exon 2 & {$[7]$} \\
& T305C & Exon 2 & {$[11]$} \\
& C297T, T300C, T312C, C396C & Exon 3 & {$[11]$} \\
\hline
\end{tabular}

cattle and it was estimated that the frequency of SNP is 1 per 89 base pairs and 1 per 92 base pairs, respectively for exons and introns. The authors suggest that a relatively high sequence variation between animals is caused by the selection pressure for different traits in cattle breeding [11].

In our studies, four Canidae species were analysed, in order to localise single nucleotide polymorphisms (SNP) and also the gene sites which have changed during the evolution of Canids. We conclude that the leptin gene is well conserved in the Canidae family. This concerns especially the dog - the SSCP technique did not reveal variability in the dog breeds studied.

The leptin protein structure consists of four antiparallel $\alpha$-helices (A, B, C and D) and is similar to that of the long-chain helical cytokine family, which includes the granulocyte colony-stimulating factor (G-CSF), the leukaemia inhibitory factor (LIF) and the ciliary neurotropic factor (CNTF). Moreover the extracellular domain of OB-R (the leptin receptor) shows homology to receptors of the gp130, G-CSF, LIF and CNTF [23]. Exploring the nr (nonredundant) database with PSI-BLAST [1] pointed out gp130 as the protein the most similar to OB-R. Gp130 is a receptor required for signal transduction by a set of ligands comprising interleukin-6 (IL-6), LIF, cardiotrophin (CT-1) and CNTF [3]. Structural similarities among cytokines, despite the absence of similarity in their amino acid sequence, suggest an equivalent model of ligand-receptor binding.

Exon 2 codes for amino acids of the A helix, which may be crucial for binding leptin to its receptor and therefore seems to be the most conservative part of the gene. Studying the cytokine-receptor recognition scheme in the case of gp130 and G-CSF-receptor showed a major role of the solvent - exposed residues 
located in the helices $\mathrm{A}$ and $\mathrm{C}$ of the ligand $[2,3]$. Hence, any changes in this part of the protein could affect leptin functions, disturbing protein-receptor interactions.

As far as exon 3 is concerned, four substitutions in our studies were identified. One of them is silent, the other changes the amino acid sequence. Codons 74, 87 and 121 code for non-conserved amino acids. Amino acids coded by codons 74 and 87 are placed in the B helix. However, the structure of the helix may remain unchanged, because of identical chemical properties of non-conserved amino acids (charged and polar, respectively). In the red fox, codon 121 codes for proline and in the other animals it codes for arginine. These two amino acids have distinctly different chemical properties. Since this substitution is located in the CD loop, we assume that it does not affect protein structure and functions.

Our studies bring some additional information about the molecular phylogeny of the leptin gene, which has already been analysed in terms of the frequency of the nucleotide substitutions in the coding sequence of 21 species belonging to 10 different orders [5]. We conclude that exon 2 is highly conserved in the Canidae family.

\section{ACKNOWLEDGEMENTS}

The study was supported by the Foundation for Polish Science (contract 13/2000).

\section{REFERENCES}

[1] Altschul S.F., Madden T.L., Schäffer A.A., Zhang J., Zhang Z., Miller W., Lipman D.J., Gapped BLAST and PSI-BLAST: a new generation of protein database search programs, Nucleic Acids Res. 25 (1997) 3389-3402.

[2] Aritomi M., Kunishima N., Okamoto T., Kuroki R., Ota Y., Morikawa K., Atomic structure of the GCSF-receptor complex showing a new cytokine-receptor recognition scheme, Nature 401 (1999) 713-717.

[3] Bravo J., Staunton D., Heath J.K., Jones E.Y., Crystal structure of a cytokinebinding region of gp130, EMBO J. 17 (1998) 1665-1674.

[4] Buchanan F.C., Fitzsimmons C.J., Van Kessel A.G., Thue T.D., Winkelman-Sim D.C., Schmutz S.M., Association of a missense mutation in the bovine leptin gene with carcass fat content and leptin mRNA levels, Genet. Sel. Evol. 34 (2002) $105-116$.

[5] Doyon C., Drouin G., Trudeau V.L., Moon T.W., Molecular Evolution of Leptin, Gen. Comp. Endocrinol. 124 (2001) 188-198.

[6] Friedman J.M., Halaas J.L., Leptin and the regulation of body weight in mammals, Nature 395 (1998) 763-770.

[7] Haegeman A., Van Zeveren A., Peelman L.J., New mutation in exon 2 of the bovine leptin gene, Anim. Genet. 31 (2000) 79. 
[8] Isse N., Ogawa Y., Tamura N., Masuzaki H., Mori K., Okazaki T., Satoh N., Shigemoto M., Yoshimasa Y., Nishi S., Hosoda K., Inazawa J., Nakao K., Structural organisation and chromosomal assignment of the human obese gene, J. Biol. Chem. 270 (1995) 27728-27733.

[9] Jiang Z.-H., Gibson J.P., Genetic polymorphisms in the leptin gene and their association with fatness in four pig breeds, Mamm. Gen. 10 (1999) 191-193.

[10] Karvonen M.K., Pesonen U., Heinonen P., Laakso M., Rissanen A., Naukkarinen H., Valve R., Uusitupa M.I.J., Koulu M., Identification of new sequence variants in the leptin gene, J. Clin. Endocrinol. Metab. 83 (1998) 3239-3242.

[11] Konfortov B.A., Licence V.E., Miller J.R., Re-sequencing of DNA from a diverse panel of cattle reveals a high level of polymorphism in both intron and exon, Mamm. Genome 10 (1999) 1142-1145.

[12] Maffei M., Stoffel M., Barone M., Moon B., Dammerman M., Ravussin E., Bogardus C., Ludwig D.S., Flier J.S., Talley M., Absence of mutations in the human OB gene in obese/diabetic subjects, Diabetes 45 (1996) 679-682.

[13] Montague C.T., Farooqi I.S., Whitehead J.P., Soos M.A., Rau H., Wareham N.J., Sewter C.P., Digby J.E., Mohammed S.N., Hurst J.A., Cheetham C.H., Earley A.R., Barnett A.H., Prins J.B., O'Rahilly S., Congenital leptin deficiency is associated with severe early-onset obesity in humans, Nature 387 (1997) 903908.

[14] Park J.P., Shared synteny of human chromosome 17 loci in Canids, Cytogenet. Cell Genet. (1996) 133-137.

[15] Patterson D., Companion animal medicine in the age of medical genetics, J. Vet. Intern. Med. 14 (2000) 1-9.

[16] Sasaki N., Shibata H., Honjoh T., Kimura K., Saito M., Ohishi I., cDNA cloning of feline leptin and its mRNA expression in adipose tissue, J. Vet. Med. Sci. 63 (2001) 1115-1120.

[17] Stratil A., Peelman L., Van Poucke M., Cepica S., A HinfI PCR-RFLP at the porcine leptin (LEP), Anim. Genet. 28 (1997) 371-372.

[18] Strobel A., Issad T., Camoin L., Ozata M., Strosberg A.D., A leptin missence mutation associated with hypogonadism and morbid obesity, Nat. Genet. 18 (1998) 213-215.

[19] Tatusova T.A., Madden T.L., BLAST 2 Sequences, a new tool for comparing protein and nucleotide sequences, FEMS Microbiol. Lett. 177 (1999) 187-188.

[20] Wayne R.K., Ostrander E.A., Origin, genetic diversity, and genome structure of the domestic dog, BioEssays 21 (1999) 247-257.

[21] Wayne R.K., Vila C., Phylogeny and Origin of the Domestic Dog, in: Ruvinsky A., Sampson J. (Eds.), The Genetics of the Dog, CAB International, Wallingford and New York, 2001, pp. 1-13.

[22] Zhang Y., Proenca R., Maffei M., Barone M., Leopold L., Friedman J., Positional cloning of the mouse obese gene and its human homologue, Nature 372 (1994) 425-431.

[23] Zhang F., Basinski M.B., Beals J.M., Briggs S.L., Churgay L.M., Clawson D.K., DiMarchi R.D., Furman T.C., Hale J.E., Hsiung H.M., Schoner B.E., Smith D.P., Zhang X.Y., Wery J.-P., Schevitz R.W., Crystal structure of the obese protein leptin-E100, Nature 387 (1997) 206-209. 